\title{
Examination of embryonic death in mares using colour Doppler and B-mode sonography
}

\author{
R. Stolla, Yen-Hui Chen and H. Bollwein \\ Gynäkologische und Ambulatorische Tierklinik der Universität München, Germany
}

\begin{abstract}
Summary
Embryonic death in mares was studied using colour Doppler sonography and B-mode sonography. The aim of this study was to characterize clinical symptoms for an impending embryonic death.

In 6 Trotter mares, who have repeatedly been pregnant, the pregnancies were interrupted with a PGF analogue (Tiaprost) at Days 15, 25, 30 and 40 . Three gestations were studied in each group (Day 30 with 4 gestations). After the PGF ${ }_{2 a}$ administration these mares were examined every 8 hours until the conceptuses were removed completely. Control groups, each made up of 3 pregnant mares, were examined daily. The size of the conceptus and the embryo/fetus, the thickness of the uterine wall, the embryonic heart rate and the Resistance Index (RI) of the A. uterina were recorded.

The embryonic heart rate could be detected in some cases at Day 18 and in all cases at Day 20 with colour Doppler sonography. It increased from 97-111 beats/min at the first detection to about 167 beats/min at the end of the first month of pregnancy. Thereafter it reached a plateau for nearly a month and increased slightly to 176 beats/min at the end of the second month of pregnancy. The embryos of the treated mares (7 of 10) showed a bradycardia (64-130 beats/min) before death; 1 had a tachycardia (209 beats/min) and 2 had normal heart rates. Beginning on Day 15, the RI values of the ipsilateral (pregnant side) uterine artery were lower than those of the contralateral. In the course of early pregnancy the RI values of uterine arteries decreased further $(P<0.01)$. In the mares treated at Day 15 this phenomenon was not observed. In the mares treated at Day 25, 30 and 40, the difference between the ipsilateral and the contralateral uterine arteries, which was significant at the beginning, disappeared 24-48 hours before embryonic death. From PGF ${ }_{2 \alpha}$ administration to embryonic death the treated mares had significantly higher Rl values on the ipsilateral uterine artery than the untreated mares $(P<0.05)$.

Sonographic characteristics of an impending embryonic death were as follows: the form of the conceptus became irregular and the thickness of the uterine wall was the same all around the embryonic vesicle. The endometrium became heterogen and estrous-like. A reduced volume of conceptual fluids, a strongly increased echogenity of the conceptual fluids and a disorganization of the conceptual membranes were the most important criteria after embryonic death.

This study shows that colour Doppler sonography is a useful method to diagnose and predict embryonic mortality in mares. Compared to Bmode sonography, embryonic mortality can be detected earlier and more reliable with the colour Doppler technique.
\end{abstract}

Keywords: mare, embryonic death, sonography, colour Doppler, B-mode

\section{Farbdoppler- und B-Bild-sonographische Untersuchungen zur embryonalen Mortalität bei der Stute}

Ziel dieser Arbeit war es, den Verlauf der embryonalen Mortalität beim Pferd mit Hilfe der Farbdopplersonographie und der B-Bild-Sonographie daraufhin zu überprüfen, ob frühzeitig klinisch relevante Merkmale erfasst werden können.

Bei 6 Traberstuten wurden in 4 verschiedenen Stadien der Frühgravidität (Stadium $1=15$. T ag, Stadium $2=25$. T ag, Stadium $3=30$. T ag, Stadium $4=40$. T ag) jeweils in 3 bzw. 4 Fällen die embryonale Mortalität durch die Applikation eines PGF ${ }_{2 \alpha}$-Analogons (Tiaprost) induziert. Die Stuten wurden nach der PGF ${ }_{2 \alpha}$-Applikation bis zum völligen Verschwinden der Fruchtanlage im Abstand von 8 Stunden untersucht. Je Stadium dienten 3 physiologische Trächtigkeiten als Kontrollen; sie wurden täglich untersucht. Als Parameter wurden die Größe des Konzeptus, des Embryos, die Dicke der Uteruswand, die Herzfrequenz des Embryos und der Resistance Index (RI) der A. uterina registriert.

Mit der Farbdopplersonographie konnte die Herzfrequenz des Embryos in Einzelfällen bereits am 18. Tag und im Regelfall ab dem 20. Tag der Gravidität festgestellt werden. Die Herzfrequenz erhöhte sich bei ungestörter Trächtigkeit ab ihrem ersten Nachweis von 97-1 11 Schlägen pro Minute bis zum Ende des 1. Trächtigkeitsmonats auf 167. Danach zeigte sich ein Plateau. Am Ende des 2 Monats nahm sie leicht auf 176 Schläge pro Minute zu. Bei den behandelten Tieren zeigten von 10 Embryonen 7 vor dem Tod eine Bradykardie (64-130 Schläge/min), 1 eine Tachykardie (209 Schläge/min) und 2 eine normale Herzfrequenz.

Ab dem 15. Tag der Gravidität wurden auf der graviden Seite kleinere RI-Werte der A. uterina festgestellt als auf der nichtgraviden. Im weiteren Verlauf sanken die RI-Werte der A. uterina des graviden Horns weiter ab $(p<0,01)$. Bei den am 15. T ag der Gravidität mit PGF behandelten Stuten war dieses Phänomen nicht zu beobachten. Bei am 25., 30. und 40. Tag der Gravidität behandelten Stuten war der Unterschied in der Blutversorgung der beiden Seiten bereits 24-48 Stunden vor dem Fruchttod nicht mehr nachzuweisen; anschließend, bis zum Fruchttod, waren die RI-Werte der graviden Seite signifikant höher als bei den Kontrollen $(p<0,05)$.

Als sonographische Merkmale eines bevorstehenden Fruchttodes wurden folgende Befunde registriert: Die Form des Konzeptus wurde unregelmäßig, während sich die Dicke der Uteruswand um den Konzeptus im Gegensatz zu einer physiologischen Gravidität nicht änderte. Das Endometrium wurde echogen und Östrus-ähnlich. Im Konzeptus traten flotierende Membranen und Schneegestöbereffekt auf. Nach dem Fruchttod waren eine verminderte Konzeptusflüssigkeit, ein Embryo mit schwächerer Echogenität, starker Schneegestöbereffekt und eine Desorganisation der Fruchthüllen die auffallendsten Befunde.

Die Farbdopplersonographie erwies sich als geeignetes Verfahren zur Diagnose und Vorhersage einer embryonalen Mortalität bei der Stute; diagnostische Befunde können mit ihr in einem früheren Stadium der Trächtigkeit und sicherer erhoben werden als mit der B-Bild-Sonographie.

Schlüsselwörter: Stute, embryonale Mortalität, Sonographie, Farbdoppler, B-Modus 


\section{Introduction}

Embryonic mortality in mares is one of the primary causes of infertility. The death of the embryo occurs most frequently in the early stages of pregnancy (Villahoz et al., 1985), especially in the first two weeks of pregnancy (Woods et al., 1987; Baker et al., 1993) and before Day 18 of pregnancy (Forde et al., 1987), respectively. In the last two decades, numerous studies examining embryonic mortality using sonography have been published. The results of these papers were gathered using B-mode sonography. The progression of an embryonic death has not been studied until now. In the past couple of years, colour Doppler sonography has been used for gynecological examinations of the mare. With the aid of this method, uterine blood flow was monitored during the estrous cycle (Bollwein et al., 1998), early stages of pregnancy (Mayer, 1999) and in later stages of pregnancy as well as the umbilical blood flow (Woschee, 1999). The aim of this study was to observe the events during the course of an ongoing embryonic death using colour Doppler and Bmode sonography. Special attention was paid to examine, if there are clinically relevant traits of embryonic mortality using colour Doppler sonography. Of these, the most important aspect was recognizing characteristics that can aid in the diagnosis of an impending embryonic death.

\section{Materials and methods}

All together 25 pregnancies in 6 Trotter mares were examined, the mares having been artificially inseminated every other day during estrous. Beginning on Day 8 after ovulation pregnancy examinations were performed (Day $0=$ ovulation).

In the experimental group embryonic death was induced during four different stages of pregnancy ( $1=$ Day 15, $2=$ Day 25, 3 $=$ Day 30 and $4=$ Day 40) by an intramuscular injection once or twice (Day 40) of 450 mg Tiaprost (PGF2-alpha analogue, Iliren C, Hoechst Roussel Vet $\mathrm{GmbH}$ ). For each stage, 3 cases were investigated except for stage 3 (Day 30) where 4 cases were examined. The mares generally came into estrous 3 to 6 days after the injection had been administered. This estrous was ignored. In the next estrous the mares were inseminated again and allocated to the control group. After that the mares were assigned to the experimental group again.

Three days before the injection of Tiaprost the mares were examined daily. After the application of $\mathrm{PGF}_{2 \alpha}$ the time interval between ultrasound examinations was shortened to 8 hours. Embryonic death was diagnosed when either the embryo's heart beat could no longer be observed or when after two consecutive ultrasonographic scans the conceptus could no longer be detected. The mares in the control group were examined daily and were not treated for the duration of the experimental stage. Following this stage the pregnancy was terminated by administering $450 \mathrm{mg}$ Tiaprost.

A colour Doppler sonograph SSH 140A (Company Toshiba, Tokyo/Japan) with a $7.5 \mathrm{MHz}$ microconvex probe was used to perform the ultrasound examinations. The B-mode of this system was applied to determine the size of the conceptus and the embryo / fetus as well as the thickness of the uterine wall.
Blood flow in the $A$. uterina was recorded by using the technique described by Bollwein et al. (1998). The Aa. uterinae of both sides were examined and the "Resistance Index" (RI) determined. This parameter is a semiquantitative indicator for blood flow resistance in the tissue distal to the point of sampling. Values are on a scale between 0 and 1 . Higher RI-values are a reflection of an increased blood flow resistance in the uterus and vice versa. The heart frequency of the embryo / fetus was determined by measuring the pulse frequency using colour Doppler sonography. Heart rate values of two measurements within one minute were averaged (Figure 1).

Statistical analysis of the data was carried out using Stat View 4.5 D (Abacus Concept, Berkeley/USA). Averages and standard deviations were calculated. In addition, Student's t-Test was applied.

\section{Results}

\section{Physiological Pregnancies}

In some cases it was possible to detect the conceptus on Day 8 or 9 of pregnancy by using a 7.5-MHz microconvex probe. The size, i.e. the diameter of the embryonic vesicle continued to increase from $1.6 \mathrm{~mm}$ on Day 8 to $24 \mathrm{~mm}$ on Day 16. Thereafter growth slowed down. Between Day 29 and Day 50 of pregnancy the conceptus grew $2.5 \mathrm{~mm}$ in diameter daily.

Using colour Doppler sonography the embryo's heart beat could be detected in some cases by Day 18, but commonly by Day 20 of pregnancy. Using B-mode sonography it was not possible to demonstrate the heart beat before Day 22 of pregnancy. On Days 18 and 19 of gestation the embryo's heart rate was between 97 and 111 beats/min (Figure 2). It increased up to 167 beats/min at the end of the first month of pregnancy, followed by a plateau between Days 31 and 50. At the end of the second month the fetus had a heart rate of 176 beats $/ \mathrm{min}$. The blood flow in the A. uterina on the pregnant side (ipsilateral) and that on the non pregnant side (contralateral) was different beginning on Day 15 (Figure 4). After this stage, blood flow on the ipsilateral side was higher resulting from the reduced RIvalues of the ipsilateral $A$. uterina which were significantly smaller compared to the contralateral A. uterina. This difference was recorded at least until Day 60 of the pregnancy. Altogether, the resistance in both uterine horns decreased throughout the pregnancy.

\section{Results after induced embryo mortality}

The interval between application of $\mathrm{PGF}_{2 \alpha}$ and the first time when the conceptus could no longer be detected varied from 88 to 288 hours. (Table 1). The exact time of embryonic death was not determinable in the mares of Stage 1 of gestation (intervention on Day 15 of pregnancy), because the embryo and its heart beat, respectively, were not detectable in this early stage of pregnancy. In the later stages (intervention on Day 25, 30 or 40 ) cardiac arrest occurred in the embryo / fetus between 56 and 128 hours after PGF ${ }_{2 \alpha}$ - administration (Table 1), whereby 
in the animals that were injected on the $40^{\text {th }}$ day of pregnancy this phenomenon was observed earlier. Of the mares that were treated on the $25^{\text {th }}, 30^{\text {th }}$ and $40^{\text {th }}$ day of pregnancy, out of 10 of the embryos, 7 showed a bradycardia before death (64130 beats/minute), 1 a tachycardia (209 beats/minute) and 2 had physiological heart rates for the stage of pregnancy.

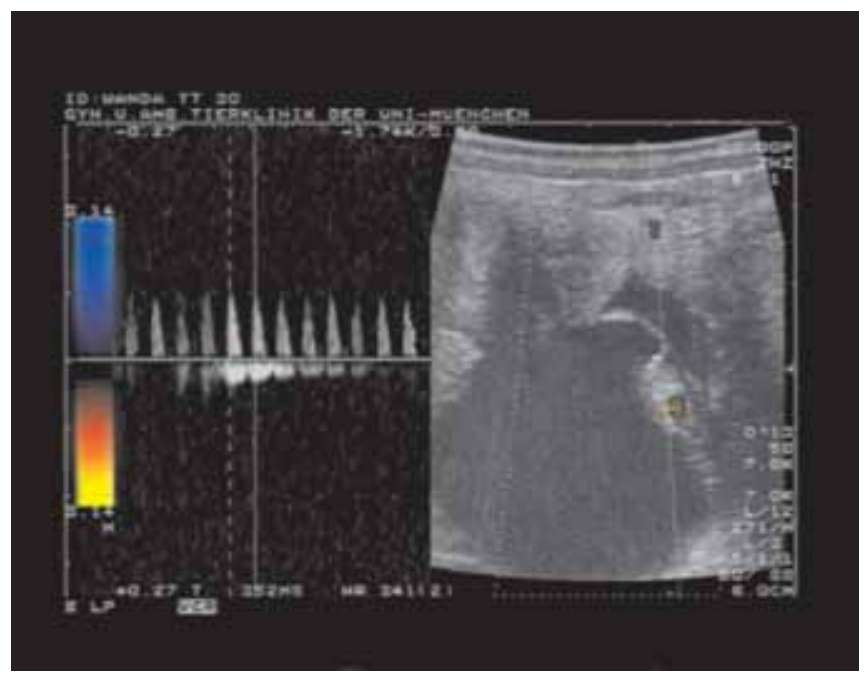

Fig. 1: Measurement of the heart frequency on an embryo on the $30^{\text {th }}$ day of pregnancy using the colour Doppler-mode.

Farbdopplersonographische Bestimmung der Herzfrequenz eines Embryos am Tag 30 der Gravidität.

The pregnancies seemed to develop physiologically in all the mares, i.e. the conceptus continued to grow until 24 to 40 hours after the injection of $\mathrm{PGF}_{2 \alpha^{\prime}}$ and then stagnated. Subsequently the embryonic vesicles showed considerable individual variations in size while such variations could not be seen during physiological pregnancies. The shape of the embryonic vesicle became irregular 32 to 64 hours after the application of $\mathrm{PGF}_{2 \alpha}$ (Table 1). In comparison, the physiological conceptus retained its compact form. An implantation of the conceptus in the 3 animals treated with $\mathrm{PGF}_{2 \alpha}$ on Day 15 did not take place. The other mares who were treated with $\mathrm{PGF}_{2 \alpha}$ after implantation

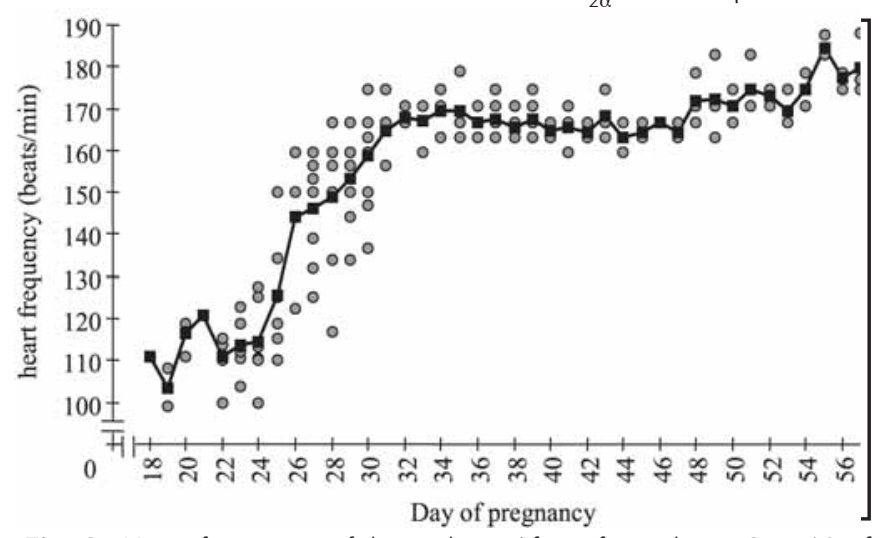

Fig. 2: Heart frequency of the embryo / fetus from days 18 to 60 of pregnancy. The values include those of the treated mares until PGF $2 a$ was injected (190 measurements in 25 pregnancies).

Herzfrequenz des Embryos/Fetus zwischen dem 18. und 60. Tag der Gravidität. Die Werte der Stuten in den Versuchsgruppen sind jeweils bis zum Zeitpunkt der Induktion des Fruchttods miterfasst (190 Messungen während 25 Graviditäten). was already established experienced a separation of the intrauterine fixation of the embryo / fetus 40 to 80 hours after treatment. Thin, floating, echointensive membranes could be found during examinations in all animals that had an induced embryonic mortality. These membranes were first seen 24 to 72 hours after the application of $\mathrm{PGF}_{2 \alpha^{\prime}}$ sometimes before embryonic cardiac arrest. At the same time in the remaining vesicular fluids small kernel-like, differing echointensive structures could be seen.

The endometrium in all of the mares treated with $\mathrm{PGF}_{2 \alpha}$ showed

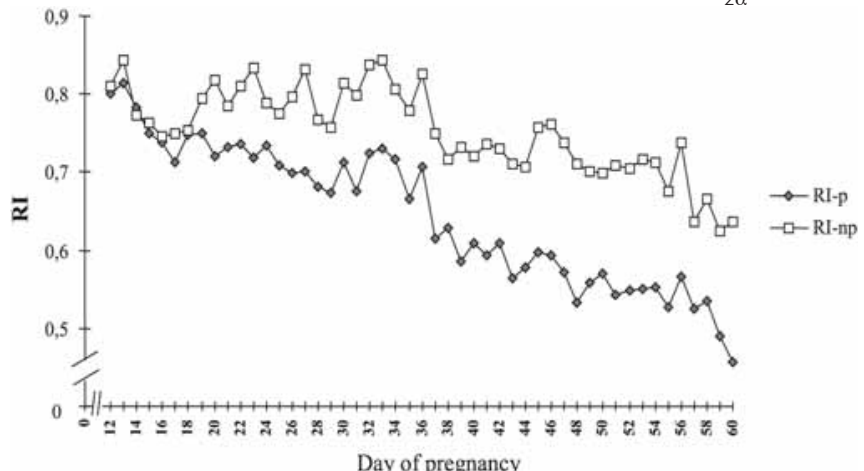

Fig. 3: Resistance Index (RI) of the Aa. uterinae in physiological pregnant mares $(\overline{\mathrm{x}} ; \mathrm{n}=3)$.

$\mathrm{RI}-\mathrm{p}=$ Resistance Index of the A. uterina of the pregnant uterine horn. $\mathrm{RI}-\mathrm{np}=$ Resistance Index of the A. uterina of the non pregnant uterine horn.

Resistance Index (RI) der A. uterina bei Stuten mit physiologisch verlaufender Gravidität (x; $n=3$ )

RI- $p=$ Resistance Index $\operatorname{der} A$. uterina des graviden Uterushorns.

RI-np $=$ Resistance Index der A. uterina des nicht graviden Uterushorns.

an estrous like structure 40 to 64 hours after treatment. In physiological pregnancies the uterine wall became thinner on the ventral side after Day 16. This phenomenon was not observed in any of the mares treated on Day 15. In the animals that experienced embryonic mortality after completion of implantation (Day 25, 30, 40), the thin portion of the uterine wall was no longer visible after 32 to 40 hours.

During the physiological pregnancies the resistance index of the ipsilateral A. uterina was smaller than that of the contralateral beginning on Day 15 (Figure 3). This reflects a higher blood flow to the pregnant uterine horn than to the non pregnant horn. In the treated mares the RI-values of both sides became equal 24 to 48 hours before the embryo died (Figure 4). From this point on there were no evident differences in blood flow.

\section{Discussion}

Numerous studies about the diagnosis of embryonic mortality have been published (Ginther, 1985b; McDowell, 1988; Ginther, 1986; Leidl and Kähn, 1989). These cases have been investigated using B-mode sonography and represent mainly single observations. The symptomatic course of an embryonic death has not been studied until now. Within the scope of this study morphological and functional changes during an embryonic death were investigated using B-mode sonography as well as colour Doppler sonography. As a model for this study mares 
undergoing embryonic mortality following PGF $_{2 \alpha}$ induced luteolysis during various stages of early pregnancy were used. It seemed appropriate to monitor the embryonic heart beat and to use changes of the heart rate as a criterion for an impending or completed embryonic death. In the first 14 to 18 days of pregnancy when the majority of embryonic losses occur (Forde et al. 1987) the heart beat could not be used to determine the time of death. Although the heart beat of the embryo could be

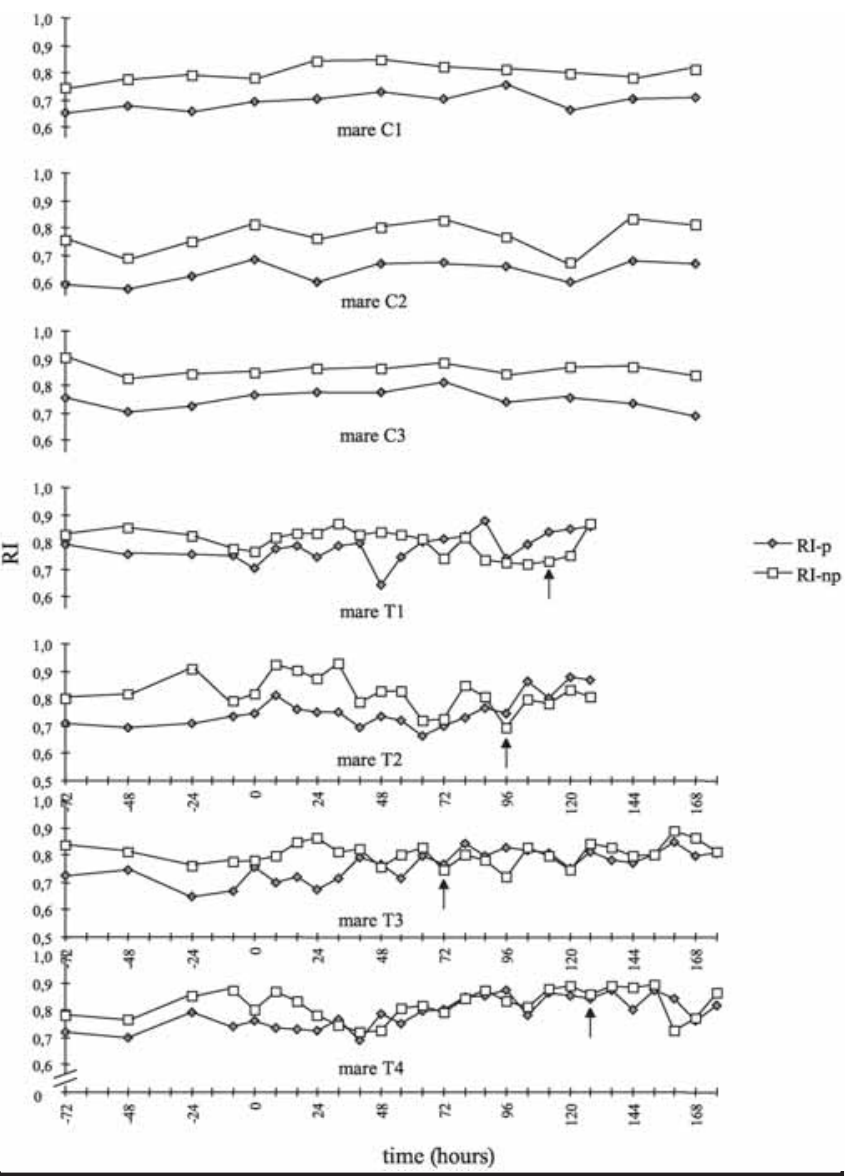

Fig. 4: Resistance Index (RI) of the Aa. uterinae in 7 pregnant mares, separated in the pregnant and the non pregnant uterine horns. The mares C1, C2 and C3 had physiological pregnancies. The mares T1, $\mathrm{T} 2, \mathrm{~T} 3$ and $\mathrm{T} 4$ were treated on the $30^{\text {th }}$ day of pregnancy with $\mathrm{PGF}_{2 \alpha}$. Hour $\mathrm{O}=$ time of the PGF ${ }_{2 \alpha}$ application, RI-p = Resistance Index of the $\mathrm{A}$. uterina of the pregnant uterine horn, $\mathrm{Rl}-\mathrm{np}=$ Resistance Index of the A. uterina of the non pregnant uterine horn, "= embryonic death.

Resistance Index (RI) der Aa. uterinae bei 7 graviden Stuten, getrennt nach gravidem und nicht gravidem Uterushorn. Bei den Stuten C1, C2 und C3 verlief die Gravidität physiologisch. Die Stuten T1, T2, T3 und T4 wurden am 30. Tag der Trächtigkeit mit PGF ${ }_{2 \alpha}$ behandelt. Stunde $0=$ Zeitpunkt der PGF ${ }_{2 \alpha}$-Applikation,

$R I-p=$ Resistance Index der A. uterina des trächtigen Horns,

RI-np $=$ Resistance Index der A. uterina des nicht trächtigen Horns,

$"=$ embryonaler Fruchttod

visualized using colour Doppler sonography in some cases on Day 18, in most cases this was not possible before Day 20 of pregnancy. As a consequence, early embryonic losses between Day 10 and 20 of gestation could not be detected by use of this method. However, assessment of the heart rate by colour Doppler sonography proved to be a valuable method to diagnose embryonic death after Day 25. In the majority of the cases (7 out of 10) a bradycardia could be detected 8 to 40 hours before cardiac arrest, that means the heart beat frequency was 20 to 30 beats/min slower than that of a physiological pregnancy. As the heart rate increases physiologically during the first month of pregnancy, repeated examinations are required during this stage of pregnancy in order to predict an embryonic death. If the heart rate fails to increase an impending embryonic death must be suspected. Additionally, the thickness of the uterine wall proved to be a useful criterion for the prediction of an embryonic death. As described by Ginther et al. (1985a), the ventral uterine wall in normal pregnant mares became thinner after Day 16, i.e. after implantation. The mares of Stage 1 (intervention on Day 15) did no show this phenomenon at any time. In the mares of the other stages receiving $\mathrm{PGF}_{2 \alpha}$ after implantation, the thickness of the ventral uterine wall increased again after the PGF injection; 16 to 32 hours before embryonic death it was as thick as the other sides of the uterine wall.

In none of the animals treated with $\mathrm{PGF}_{2 \alpha}$ on Day 15 the implantation of the conceptus did occur. In mares receiving $\mathrm{PGF}_{2 \alpha}$ during a later stage of gestation (intervention on Day 25, 30 , or 40 ) the fixation of the conceptus to a specific area in the

Tab. 1: Time (hours) of occurrence of irregular form of the conceptus (IC), disappearance of fixation (DF), disappearance of the heartbeat (DH) of the embryo/fetus, disappearance of the conceptus (DC) after injection of $\mathrm{PGF}_{2 \alpha}$ on Days 15, 25, 30 and 40.

Zeitliches Auftreten (Stunden) verschiedener embryonaler Veränderungen nach Injektion von $P G F_{2 a}$ am 15., 25., 30. bzw. 40. Tag der Gravidität.

IC = Irreguläre Form des Konzeptus, DF = Fixation nicht mehr nachweisbar, DH = Herzaktion nicht mehr nachweisbar, DC = Konzeptus nicht mehr nachweisbar

\begin{tabular}{|c|c|c|c|c|c|}
\hline $\begin{array}{l}\text { Day of } \mathrm{PGF}_{2 \mathrm{a}}- \\
\text { injection }\end{array}$ & Mare & IC & DF & $\mathrm{DH}$ & $D C$ \\
\hline \multirow[t]{3}{*}{15} & $A$ & 56 & - & - & 136 \\
\hline & B & 56 & - & - & 88 \\
\hline & C & 64 & - & - & 168 \\
\hline \multirow[t]{3}{*}{25} & A & 40 & 40 & 64 & 88 \\
\hline & B & 40 & 64 & 112 & 136 \\
\hline & C & 40 & 70 & 96 & 96 \\
\hline \multirow[t]{4}{*}{30} & A & 32 & 48 & 128 & 312 \\
\hline & B & 40 & 48 & 72 & 152 \\
\hline & $\mathrm{Cl}$ & 56 & 64 & 96 & 96 \\
\hline & C2 & 40 & 56 & 120 & 120 \\
\hline \multirow[t]{3}{*}{40} & $\mathrm{D}$ & 40 & 72 & 56 & 216 \\
\hline & $E$ & 56 & 80 & 64 & 96 \\
\hline & $\mathrm{F}$ & 56 & 80 & 56 & 288 \\
\hline
\end{tabular}


uterus was lost. According to Ginther (1986) this change in position of the placental sac after implantation is an important indication for an imminent embryonic death.

The shape of the conceptus also provides useful information for the diagnosis of an impending embryonic death. In contrast to physiological pregnancies, uterine contractions and intraabdominal pressure changes caused passive changes to the form of the dying embryo.

Additional important sonographic observations that indicate an embryonic death include floating membranes, that were observed before cardiac arrest, and echogenic particles in the vesicle fluids. These particles are only present in the first three months of an impaired pregnancy. The echogenic particles are cellular components of an ongoing resorption of an embryo (Leidl and Kähn, 1989).

Other sonographic findings, for example the size of the conceptus and the length of the embryo/fetus, were less suitable to predict and diagnose an embryonic mortality because the difference to the physiological pregnancies were not distinct. The results of this study show that colour Doppler sonography is a valuable method to predict and diagnose early embryonic mortality. This technique permits the investigation of embryonic vitality and uterine blood supply approximately from the $18^{\text {th }}$ day of pregnancy on. Using colour Doppler and B-mode sonography indications of an impending embryonic death can be obtained. Unnecessary intervention to the uterus with a twin pregnancy can be avoided if one of the embryos is showing signs of an embryonic death. When compared to B-mode sonography, colour Doppler sonography has definite advantages: the criteria for an impending death of the embryo itself can be recognized earlier and more reliably. In summary, colour Doppler sonography can improve the diagnosis of disorders during early pregnancy in mares.

\section{Literature}

Baker, C. B., Little, T. V. and McDowell, J. (1993): The live foaling rate per cycle in mares. Equine Vet. J., Suppl. 15, 28-30.

Bollwein, H., Maierl, J., Mayer, R. and Stolla, R. (1998): Transrectal color doppler sonography of the A. uterina in cyclic mares. Theriogenology 49, 1483-1488.
Forde, D., Keenan, L., Wade, J., O'Connor, M. and Roche, J. F. (1987): Reproductive Wastage in the mare and its relationship to progesterone in early pregnancy. J. Reprod. Fert., Suppl. 35, 493-495.

Ginther, O. J. (1985a): Embryonic loss in mares: incidence, time of occurrence, and hormonal involvement. Theriogenology 23, 7789.

Ginther, O. J. (1985b): Embryonic loss in mares: nature of loss after experimental induction by ovariectomy or prostaglandin $F_{2 a}$. Theriogenology 24, 87-98.

Ginther, O. J. (1986): Ultrasonic imaging and reproductive events in the mare. Equiservices Publishing, Cross Plains, Wisconsin.

Griffin, P. G., Carnevale, E. M. and Ginther, O. J. (1993): Effects of the embryo on uterine morphology and function in mares. Anim. Reprod. Sci. 31, 311-329.

Leidl, W. and Kähn, W. (1989): Ultrasonic characteristics of pathological conditions of the equine uterus and ovaries. In: Diagnostic ultrasound and animal reproduction, Eds.: Taverne, M. M. and Willense, A. H., Kluwer Academic Publishers, 21-35.

Mayer, R. C. (1999): Farbdopplersonographische Untersuchung der Arteria uterina und des Corpus luteum während des Zyklus und der Frühgravidität der Stute. Vet. Med. Diss., München.

McDowell, K. J., Sharp, D. C., Grubaug, W., Thatcher, W. W. and Wilcox, C. J. (1988): Restricted conceptus mobility results in failure of pregnancy maintenance in mares. Biol. Reprod. 39, 340-348.

Villahoz, M. D., Squires, E. L., Voss, J. L., Shideler, R. K. (1985): Some observations on early embryonic death in mares. Theriogenology 23, 915-924.

Woods, G. L., Baker, G. B., Baldwin, J. L., Ball, B. A., Bilinski, J., Cooper, W. L., Ley, W. B., Mank, E. C., Erb, H. N. (1987): Early pregnancy loss in brood mares. J. Reprod. Fert., Suppl. 35, 455-459.

Woschee, I. (1999): Farbdopplersonographische Untersuchung der Arteria uterina, Arteria ovarica und Arteria umbilicalis während der Gravidität und des Puerperiums der Stute. Vet. Med. Diss., München.

Prof. Dr. R. Stolla

Gynäkologische und Ambulatorische

Tierklinik der Universität München

Königinstr. 12

80539 München

Tel.: 0049-89-21802612

Fax.: 0049-89-21802161

e-mail: rudolf.stolla@gyn.vetmed.uni-muenchen.de 